International Journal of Agriculture, Environment and Bioresearch

Vol. 4, No. 06; 2019

ISSN: $2456-8643$

\title{
ANALYSIS OF SOLID WASTE COLLECTION AND MANAGEMENT IN CALABAR SOUTH, CROSS RIVER STATE-NIGERIA
}

\author{
Emri, S. Inaku ${ }^{1}$, Nwafor, S. Emeka ${ }^{2}$ and Ernest B. Irem $^{3}$ \\ ${ }^{1 \& 3}$ Department of Urban and Regional Planning Cross River University of Technology, Calabar-Nigeria \\ ${ }^{2}$ Department of Architecture Cross River University of Technology, Calabar-Nigeria \\ http://doi.org/10.35410/IJAEB.2019.4496
}

\begin{abstract}
The major problems plaguing most urban areas in developing countries like Nigeria is the inability of constituted authority to strategize on how to carry out their responsibility of removing waste from our environment. The paper investigated solid waste collection and management in Calabar South. A total of 396 (three hundred and ninety six) questionnaires were randomly distributed to residents in the twelve (12) wards of the Local Government Area to elicit information on the availability of designated collection point. Findings reveal that $43.43 \%$ of the respondents lack where to dispose their waste with only $18.69 \%$ having access, why the remaining $37.88 \%$ complained of inadequacy of area designated as collection point. The condition of the bins located at this designated point shows that 13(20\%) are in good (intact) shape, $21(32.31 \%)$ are in bad shape but serviceable, while $31(47.69 \%)$ are in bad shape and are not unserviceable. It was recommended that more collection areas be created in addition to existing ones. Two or more micro dumpsters should be stationed at disposal site(s), within Central Business Districts and high density residential areas. A trek able distance of between $150 \mathrm{~m}-250 \mathrm{~m}$ is ideal as a range for residents to cover to dispose waste. Different avenues like media, workshops, seminars, school, and symposia should be explored by the government to sensitize the public on the dangers of indiscriminate refuse dumping.
\end{abstract}

Keywords: Solid Waste, Collection point, Management.

\section{INTRODUCTION}

Waste is an inevitable useless by-product of man's actions. As man engage in the production of goods and services, consumption of goods and recreational activities, waste is generated. Waste is further categorized into solid, liquid and gaseous waste. Solid wastes are generated from domestic, industrial and other human actions on planet earth. These activities which is as a result of man's quest to live a comfortable life and his refusal to take responsibility for the management of the waste that has constituted threat to human race and the environment he lives in. According to UNEP (2005), the growth of the world's population, increasing urbanization, rising standards of living, and rapid development in technology have all contributed to an increase in both the amount and variety of solid waste generated by industrial, domestic and other activities. Huge volumes of wastes are generated and transported and finally disposed of. These operations have to be carried out speedily and efficiently without incurring excessive cost or damage to the 
environment. Regrettably in many developing countries the system of managing waste is primitive and cannot cope with huge volumes of wastes being generated.

The problems of dealing with great volume of waste materials are particularly acute in developing countries, as most cities are faced with the problem of population increase, urban sprawl and sub urban development. These situations have no doubt brought increasing strain on urban facilities. One area in which this strain has become most obvious is in waste collection and management, where the existing system appears to be incapable of coping with the issue of evacuating load of waste generated and heaped on the surface of the earth. Virtually all aspects of man's productive activities involve the generation of waste (Oyinloye, 2012). Similarly, Ubachukwu, Phi-Eze and Emeribe (2014) sees municipal waste as an important percentage of waste produced by different activities carried out by humans. The way these wastes are handled, stored, collected and disposed can pose risk to the environment and to public health.

The problem of waste collection and management is especially severe in most developing countries where poor planning and lack of adequate resources contribute to the poor state of municipal solid waste management. Waste collection is the starting point of waste management process and this collection can be carried out in varied forms: house to house, communal (dumpsters to waste truck) for onward transportation to disposal site. Waste management is a global environmental issue, seen from a very simple angle waste management refers to a judicious use of every available means to treat disposable by-products in such a manner that they do not constitute nuisances to the environment. Solid waste management in urban areas is one major problem facing city planners all over the world. Solid waste management involves scientific processes that include collection, transportation and disposal of waste products in an economically feasible and environmentally viable way. This is what is eluding most cities in developing countries like Nigeria particularly Calabar South which is one of the eighteen (18) local governments areas in Cross River State. The study area has a fair share of this problem of waste collection and management that is seen in most urban areas in Nigeria. Issues ranging from inadequate to lack of micro waste collection points, irregular pick up time and clear state of abandonment of locations previously designated as collection points characterized waste management activities in the study area.

According to Onibokun and Komuyi, (1996), cities in Nigeria being among the fast growing cities in the world are faced with the problem of solid waste generation. This statement is supported by Uchegbu, (2002) as he asserted that "the growth in the urban inhabitant is accompanied by a growth in the production of various categories of municipal waste". He also postulated that "the magnitude of waste management in Nigeria is enormous". Solid waste constitutes one of the environmental concerns in Nigeria. Ajadike, (2001) said that urban waste crisis arises because of three fundamental factors, namely; rapid increase in urban population, heavy consumption pattern of urban dwellers and inefficiency of the authorities whose statutory responsibilities includes efficient waste management in cities.

The beauty of any environment lies on its good sanitary condition. This is so because, when an environment is clean it has positive bearing on the wellbeing of residents and their lives are not threatened by diseases and illness. It is often said that cleanliness is next to Godliness, thus it is 
expected of man to clean up his environment by disposing the refuse generated by his actions. However there is departure from the ethical expectation of man with regard to disposal of garbage in urban areas in Nigerian arising from inadequate strategy for waste collection. One of the environmental problems facing cities in both developing and developed nations is the collection and disposal of household waste. The Awake, (1990) laments that man who has travelled to the moon and back, descended into depths of oceans, harnesses the elusive atom, and developed computers, cannot take out their own household garbage and dispose of it properly; thereby freeing their generation from the fear of being buried alive in it. One cynic has observed that garbage is one of Japanese export without a market.

It is apparent that issues concerning inadequate municipal solid waste micro disposal site, delay in evacuation of refuse from micro disposal sites, rapid disappearance of the few available collections bins due to wear and tear, none consideration of threshold and range in the location of micro disposal sites are germane issues that need to be addressed. It is only then that indiscriminate disposal of waste by some residents who prefer to dump waste along roadsides, into drainages and other water passage during rainy season will be easy to nib in the bud. Thus the resultant effects; such as flooding, vector breeding place for mosquitoes and rodents; unpleasant odor, eyesore and filthy landscape will be confined to the past. Especially, if the inadequacy of waste collection points are addressed by creating pattern for the designation of municipal solid waste collection sites.

The aim of this study is to examine the vulnerability of wards/neighbourhoods in Calabar South to the menace of indiscriminate solid waste dump due to inadequate/Absent of designated collection point with a view to making a proposal that will promote efficient collection, transportation and disposal of solid waste in the study area.

The Objectives of the study are:

1. To create a data base for municipal solid waste micro collection points and management in Calabar South.

2. To assess the condition of the bins located at the collection points.

3. To identify the areas with high activities and indiscriminate dumpsites within the study area.

4. To proffer solutions through predictive model on waste collection and management in the study area.

\section{Study Area}

Calabar South Local Government is the study area. It is located on Latitude $4^{0} 55^{\prime} \mathrm{N}$ of the equator and longitude $8^{0} 16^{\prime} \mathrm{E}$ of the Greenwich meridian, it is bounded to the north, south, east and west by Calabar Municipality, Atlantic ocean, Akpabuyo and Odukpani Local Government Areas respectively. The area is flanked on its eastern and western borders by two rivers, the Great Kwa and Calabar River. The local government was created from Calabar Municipality on the $12^{\text {th }}$ of December, 1996. The local government is comprised of two major ethnic groups namely the Efiks and Efuts. However, other immigrant ethnic groups such as Igbos, Yoruba, Hausa, Ibibios, Annangs, Orons, and other ethnic groups from the Central and Northern 
Senatorial Districts of Cross River State. The population of Calabar South in 2006 was 191,515 (NPC), projected to 2019 at $3 \%$ growth rate bring the population to 278095 . The climate of the area is humid tropical although rainfall occurs throughout the year. The place experiences double maxima, rainfall regime in July and September. The area has a high relative humidity usually between $80 \%$ and $100 \%$ and vapour pressure in the air averaged 29 millibars throughout the year. High salinity $(3.8 \pm 0.4 \%)$ is limited to the dry season while lower salinity $(0.5 \pm 0.6 \%)$ occurs in the rainy season (Ukpong1995). Geologically, the area is composed of tertiary sandy deposits. These are overlain by quaternary silty and clayey alluvium eroded from massive preCambrian rocks of Oban hills in the outskirts. This characteristics poorly consolidated, non cohesive and porous rock formation permits large accumulation of water through constant and occasional flooding of the ecological zone. Floodwater recession or tidal retreat permits deposition of alluvial fans and levees quite supportive of plant growth. It accounts for occupational engagement in market gardening among dwellers. The soils are sandy; light hued in some location, but clayey, muddy, dark grey in colour, water logged and boggy. However, saline mangrove soils, developed on mud, sand or peat at the mouths of estuaries inundated by tropical tide water's (Ukpong1995). Politically the local government headquarters is Anantigha, and has a total of twelve (12) wards for administrative convenience. It has rich mangrove swamp vegetation with variety of hard wood and raffia palm. The vegetation is enhanced by the aquatic deposit due to its strategic location between the rivers.

\section{MATERIALS AND METHOD}

The method adopted for this research is the survey design. Both primary and secondary sources were employed to collect data. Primary sources of data employed in the study were observation, interview and questionnaire administration to acquire data from resident on waste collection and management within the study area. Secondary data like literatures were gathered from journal, text book, internet, while the population of the study area was acquired from National Population Commission (NPC), and records of approved waste collection points, from Cross River State Ministry of environment.

Data on both approved and illegal waste collection points were noted and recorded, the type and number of waste bins located at collection point, the condition of the bin(s) and the frequency of the evacuation of the waste from the collection point were all captured in the questionnaire. Three hundred and ninety six (396) questionnaires were distributed among the twelve (12) wards that make up the local government.

The study sample size was statistically determined using "Taro Yamane" (1967) formula:

$$
n=\quad \begin{aligned}
& N \\
& -1+N(e) * 2
\end{aligned}
$$

Where:

$n$ is the sample size; 
$N$ is the finite population,

$e$ is the level of significance (limit of tolerable error), that is $0.05(5 \%)$ and

1 is unity (a constant)

Using the sampling frame formula with a projected population of 278095, 396 respondents (approximately 400) were sampled randomly and administered with questionnaire.

\section{RESULT}

Table 1: Analysis of solid waste collection points in Calabar South

\begin{tabular}{|l|l|l|l|l|}
\hline SN & Ward & Shape Area $\left.\mathbf{M}^{2}\right)$ & $\begin{array}{l}\text { Micro Disposal } \\
\text { Sites }\end{array}$ & $\begin{array}{l}\text { Percentage/ } \\
\text { Ward }\end{array}$ \\
\hline 1 & 1 & $716,440.513314$ & 06 & 9.24 \\
\hline 2 & 2 & $128,707.284327$ & NIL & 0.00 \\
\hline 3 & 3 & $93,506.224375$ & 01 & 1.54 \\
\hline 4 & 4 & $317,286.180718$ & 01 & 1.54 \\
\hline 5 & 5 & $599,090.877039$ & 03 & 4.62 \\
\hline 6 & 6 & $361,186.524929$ & 02 & 3.08 \\
\hline 7 & 7 & $147,492.835161$ & 01 & 1.54 \\
\hline 8 & 8 & $1,509,713.566173$ & 03 & 4.62 \\
\hline 9 & 9 & $7,52,422.345977$ & 03 & 4.62 \\
\hline 10 & 10 & $690,553.627078$ & 05 & 7.69 \\
\hline 11 & 11 & $3,592,006.288157$ & 14 & 21.53 \\
\hline 12 & 12 & $9,638,286.853575$ & 26 & 40.00 \\
\hline TOTAL & $\mathbf{1 2}$ & $18,446,793.120825$ & 65 & 100 \\
\hline
\end{tabular}


Table 1: shows that a total of sixty five (65) solid waste collection sites are located in Calabar South Local Government Area. Ward 3, 4, and 7, have one location each, Ward 5, 8 and 9 has three each. While ward 12 has the highest (26) number of municipal solid waste collection sites, ward 2 have none. The total land area covered is $18,446,793.120825 \mathrm{~m}^{2}$ (18.446 Hectares) and with a projected population of (278095), it translates to 4278 persons per bin in Calabar South.

Table 2: Analysis of the type of bins located at collection centre.

\begin{tabular}{|l|l|l|}
\hline Type of bin & Number & Percentage \\
\hline Skip & 41 & 61.54 \\
\hline Compactor & 24 & 38.46 \\
\hline Total & $\mathbf{6 5}$ & $\mathbf{1 0 0}$ \\
\hline
\end{tabular}

Source: Field survey, 2019

The types of bins station at collection point are mainly of two types (skip and compactor). The skip bins constitute $61.54 \%$, while the compactor bin constitutes $38.46 \%$ of the bins at collection centre. This is also shown in figure 1.

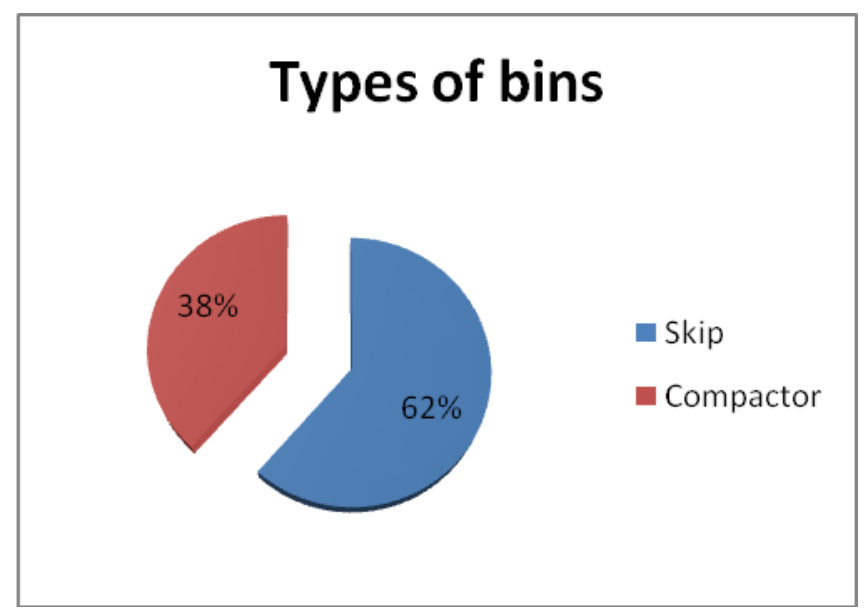

Figure 1: Pie chart depicting the analysis as contained in table 2. 
International Journal of Agriculture, Environment and Bioresearch

Vol. 4, No. 06; 2019

ISSN: $2456-8643$

Table 3: Analysis of the condition of bins located at collection centre.

\begin{tabular}{|l|l|l|}
\hline CONDITION OF BIN & Number & Percentage \\
\hline Intact & 13 & 20.00 \\
\hline Bad(serviceable) & 21 & 32.31 \\
\hline Bad (unserviceable) & 31 & 47.69 \\
\hline Total & $\mathbf{6 5}$ & $\mathbf{1 0 0}$ \\
\hline
\end{tabular}

Source: Field survey, 2019

It is reveal from table 3 that out of sixty five bins located at collection points, 13(20\%) are in good (intact) shape, 21(32.31\%) are in bad shape but serviceable, while 31(47.69\%) are in bad shape and are not unserviceable. See figure 2, 3, 4 and 5 for the condition of bins in the study area.

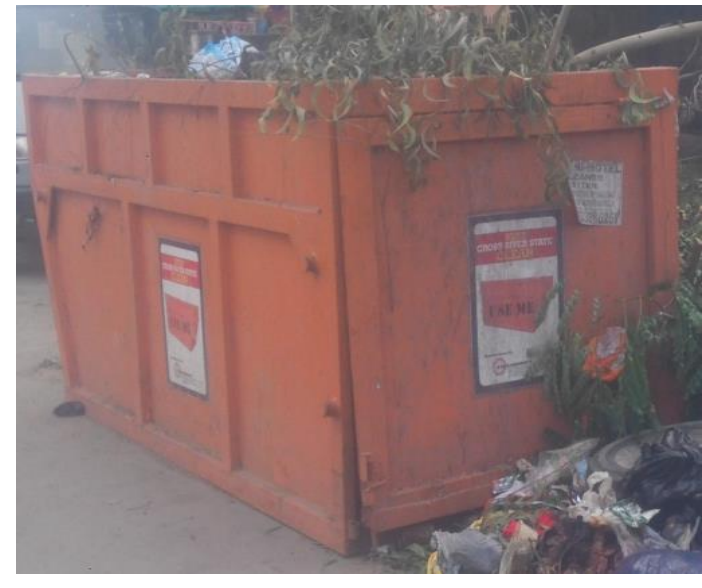

Plate i: Intact Bin

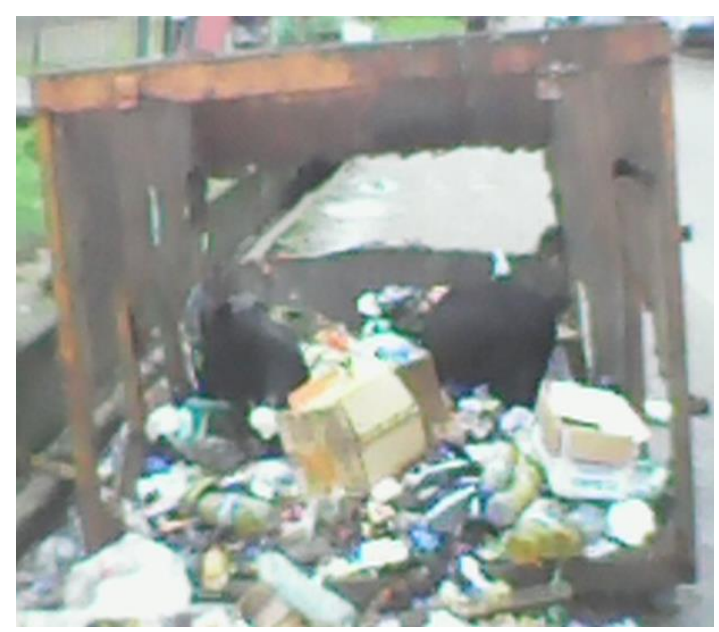

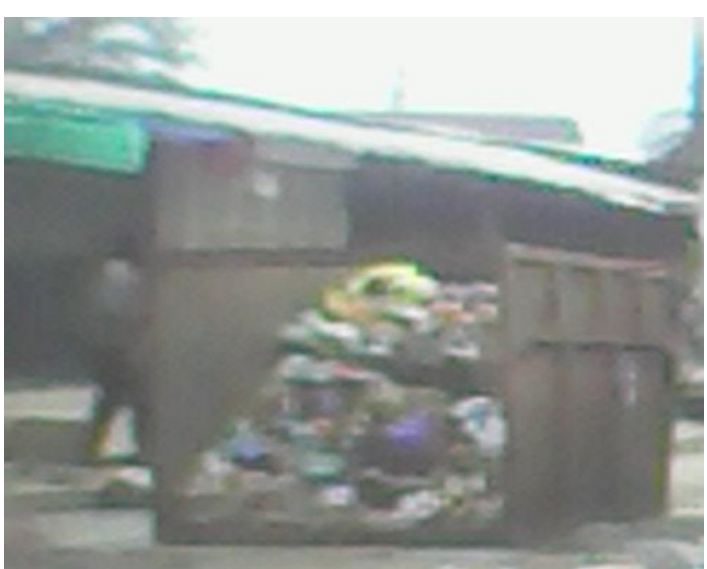

Plate ii: Bad (Serviceable) Bin

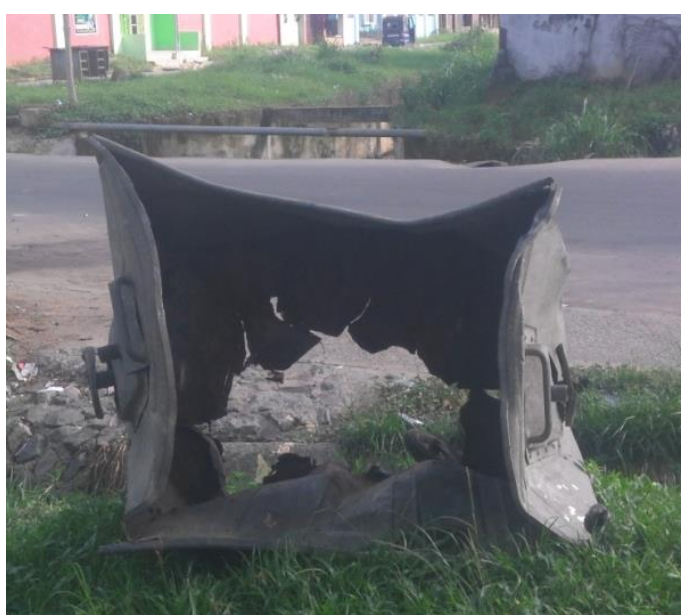


Table 4: Analysis of respondent opinion on availability of collection points

\begin{tabular}{|l|l|l|l|l|l|}
\hline Ward & Adequate & Inadequate & Lacking & Total & Percentage \\
\hline 1 & $9(27.27 \%)$ & $18(54.55 \%)$ & $6(18.18 \%)$ & 33 & 8.33 \\
\hline 2 & - & - & $33(100 \%)$ & 33 & 8.33 \\
\hline 3 & - & $12(36.36 \%)$ & $21(63.64 \%)$ & 33 & 8.33 \\
\hline 4 & - & $11(33.33 \%)$ & $22(66.67 \%)$ & 33 & 8.33 \\
\hline 5 & $3(9.09 \%)$ & $13(39.40 \%)$ & $17(51.51 \%)$ & 33 & 8.33 \\
\hline 6 & - & $18(54.55 \%)$ & $15(45.45 \%)$ & 33 & 8.33 \\
\hline 7 & - & $14(42.42 \%)$ & $19(57.58 \%)$ & 33 & 8.33 \\
\hline 8 & $5(15.15 \%)$ & $15(45.45 \%)$ & $13(39.40 \%)$ & 33 & 8.33 \\
\hline 9 & $8(24.25 \%)$ & $14(42.42 \%)$ & $11(33.33 \%)$ & 33 & 8.33 \\
\hline 10 & $15(45.45 \%)$ & $12(36.36 \%)$ & $6(18.18 \%)$ & 33 & 8.33 \\
\hline 11 & $18(54.55 \%)$ & $10(30.30 \%)$ & $5(15.15 \%)$ & 33 & 8.33 \\
\hline 12 & $16(48.48 \%)$ & $13(39.40 \%)$ & $4(12.12 \%)$ & 33 & 8.33 \\
\hline Total & $\mathbf{7 4 ( 1 8 . 6 9 \% )}$ & $\mathbf{1 5 0 ( 3 7 . 8 8 \% )}$ & $\mathbf{1 7 2 ( 4 3 . 4 3 \% )}$ & $\mathbf{3 9 6}$ & $\mathbf{1 0 0}$ \\
\hline
\end{tabular}

Source: Field survey, 2019

Residents views as regards their experience as it concerns the availability or unavailability of collection point(s) in their neighbourhoods shows that 74 respondents representing $18.69 \%$ are satisfied with the number of collection points in their area, 150 respondents representing $37.88 \%$ are of the opinion that the available collection point are inadequate, while 172 respondents that constitutes $43.43 \%$ are of the view that collection point is lacking in their location. This information is graphically presented in figure 2 . 


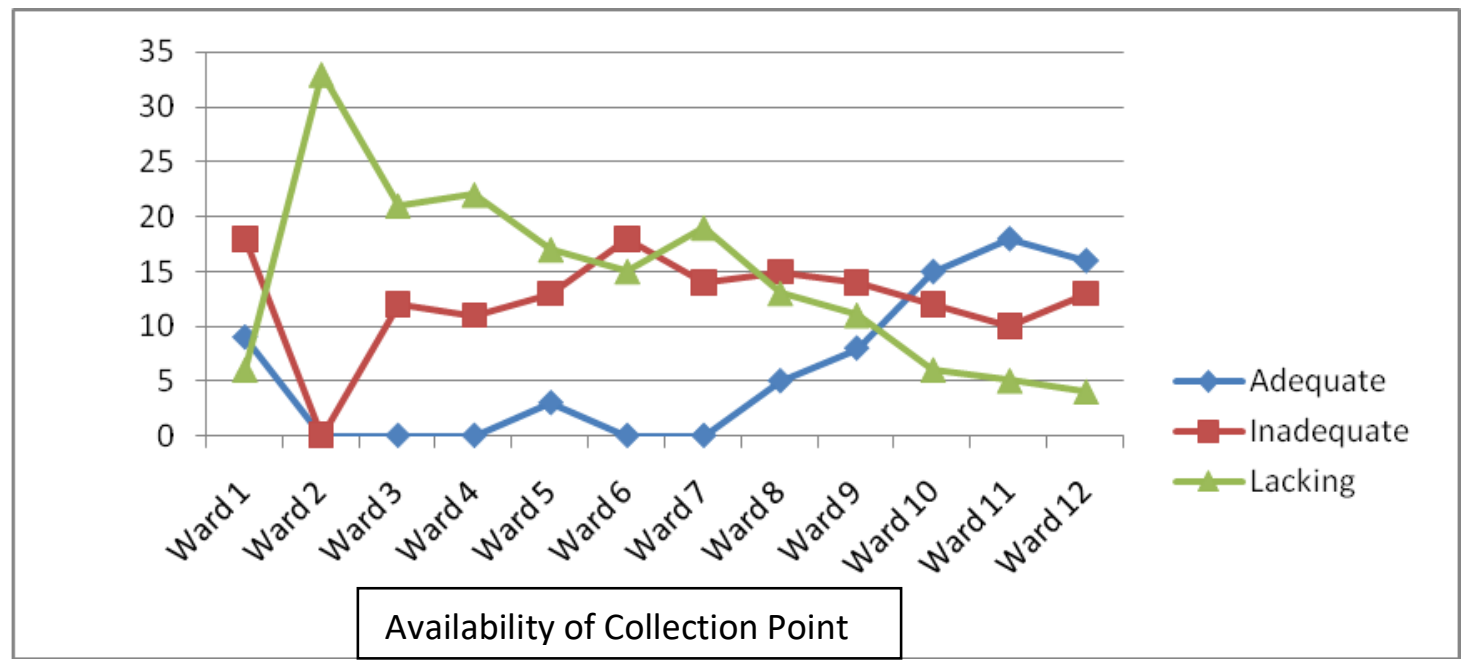

Figure 2: Line chart of the level of availability of collection point.

\section{FINDINGS:}

The issue of inadequacy of dumpsters in terms of quantity as shown in table 4 and figure 2 is a challenge. This is obvious within the Central Business District (CBD) and in some residential neighbourhoods. It was discovered that no single area is designated as collection point in ward 2. The Central Business District being the centre of activities and densely populated area ought to be given preference in terms of designated temporal disposal sites but this is not the reality on ground. The effect of this inadequacy has manifested in over flow of waste as evident in plate $v$

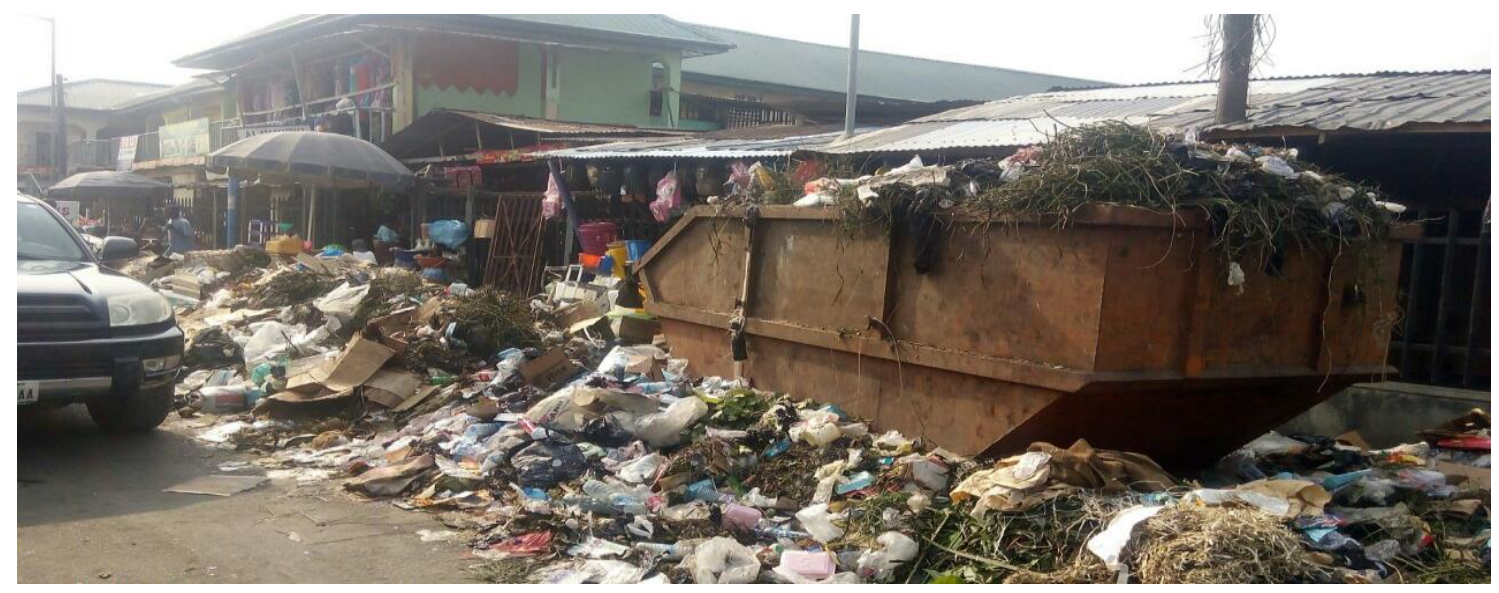

Plate v: An over flow collection point at Watt Market (CBD)

The absence of compactor trucks, in a situation where we have compactor bins is a misnomer this has often led to use of open vehicles (tipper, pick-up etc) to evacuate wastes from this temporal disposal sites which normally inhibit the rate of evacuation. The consequence include incomplete clean-up, more time used in cleaning up the site and litters on the routes taken by this open vans which most times are not covered to the final dumpsite. 
Poor funding is one of the challenges that are affecting effective discharge of duty by the authorities concerned. However, this is not peculiar to Cross River State Waste Management Agency, as earlier researchers Agunwamba, (2008), Ogwueleka, (2009) and Ezeah and Roberts (2012) have identified inadequate funding as one of the major factors affecting solid waste management in Nigeria. Ogwueleka (2009) went further to say that environmental agencies do not have the capacity to perform their duty effectively due to limited budget.

There are no criteria for designating collection point, collection points are located on roundabout, at close proximity $(3 \mathrm{~m})$ to junction as seen along Ekpo Abasi street by Mayne Avenue among others. Iro, Okorondu, Mbano and Duru (2012) adopted criteria which set require distant of the dumpsters from roads $(10 \mathrm{~m})$, water bodies $(70 \mathrm{~m})$, public areas $(40 \mathrm{~m})$, commercial areas $(20 \mathrm{~m})$, residential areas $(20 \mathrm{~m})$ and from one another not less than $(100 \mathrm{~m})$ this standard is not followed due to availability of fewer tarred road hence there is concentration of collection point along tarred roads neglecting the standards.

Other factors discovered to inhibit effective waste management system in Calabar South include but not limited to: Inadequate collection point, poor condition of the bins, limited number of waste collection trucks, poor legislation of environmental laws, absence of waste management alternatives and poor environmental public awareness, conflicting roles and absence of synergy among authorities saddled with the responsibility of freeing the study of filth.

\section{RECOMMENDATION}

The challenges of inadequate and lack of designated collection point can be handled by creating more collection area(s) to cater for residents in these areas where there is none, also by providing two or more micro dumpsters at disposal site(s), within Central Business Districts and high density residential areas.

The absence of personnel to direct little kids on how to empty their waste into dumpsters was noticed, this has led to filthy environment. The absence of personnel (Site men) at these collection points is a disservice as some of these kids due to height challenges are incapable of discharging waste in their container into the receptacle properly. The engagement of personnel to oversee the site will be a good strategy to keep the site tidy as this will complement the services of the "Green Sheriff" that are saddled with the responsibility of monitoring evacuation.

The maximum distance residents are willing to walk to the municipal micro disposal sites to deposit their waste should be considered in the creation of new collection point. A trek able distance of between $150 \mathrm{~m}-250 \mathrm{~m}$ is ideal as a range for residents to cover to dispose waste. This implies that the minimum distance between bins should be $300 \mathrm{~m}$, while this distance should reach a maximum of $500 \mathrm{~m}$ and anything beyond this will lead to indiscriminate dumping of waste.

Sensitization need to be made on adverse effects inherent in the abuse of our environment through indiscriminate refuse disposal system. Different avenues like media, workshops, seminars, school, and symposia should be explored by the government in order to create public awareness on the dangers of indiscriminate refuse dumping. Participation of public in the planning and implementation of solid waste management should also be encouraged through creating awareness 


\section{CONCLUSION}

The study examine the vulnerability of wards/neighbourhoods in Calabar South to the menace of indiscriminate solid waste dump occasion by inadequate designated area as temporal waste deposit sites in Calabar South-Nigeria. It was discovered that the absence of criteria for the creation of location to enable residents dispose their waste product with minimum energy has contributed to the filthy nature of some areas in the study area. The poor state of our roads, poor condition of the bins, inadequate bins as well as inadequate funding have affected the state of the environment in the study area negatively. The spate of incessant illegal dumps within the study area is an indication of inadequacies in terms of handlers of the planning of the distribution pattern of the collection points.

\section{REFERENCES}

Agumwaba, J. C. (2008). Solid waste management in Nigeria: problems and issues, Journal Environmental Management. 22, (6), 849-856,

Ajadike, J. C. (2001) Urban solid waste management in Nigeria in G.E.K. Ofomata and P. O. PhilEZE (eds). Geographic perspective on environmental problems in Nigeria. Nsukka Department of Geography, University of Nigeria Nsukka

Awake (1990) "Do The Forest Have a Future" in Rain Forests: under siege. March 22, 1990.

Ezeah, C., Roberts, C. L., (2012) Analysis of barriers and success factors affecting the adoption of sustainable management of municipal solid waste in Nigeria. https://www.ncbi.nlm.nih.gov/pubme d/22459066

Iro, S. I. Okorondu, U. V. Mbano, E and Duru P (2012). "Implications of Geographic Information System in Mapping Solid Waste Collection Points in New Owerri, Imo State". International journal of science and Technology Bashir Dar, Ethiopia Vol. 1 No. 1, pp 6069

Ogwueleka, T. C. (2009) Municipal Solid Waste Characteristics and Management in Nigeria. Iran Journal of Environment Health Science Engineering Available at http://Journal/situms.ac.ir

Onibokun, A. G and Kumuyi, A. J (1996) Urban Poverty in Nigeria: towards sustainable strategies for its alleviation. Centre for African Settlement Studies and Development, Ibadan, Nigeria. CASSAD Monograph Series 10.pp.1-2. 
Oyinloye, M. A. (2012): Using GIS and Remote Sensing in Urban Waste Disposal and Management: A Focus on Owo L.G.A, Ondo State, Nigeria. European International Journal of Science and Technology. 2304-9693 www.eijst.org.uk

Ubachukwu, N. N., Phil-Eze, P. O. and Emeribe, C. N. (2014). Analysis of Household Harzardous Waste Awareness Level in Enugu Metropolis. Academic Journal of Interdisciplinary Studies Vol 3. No1. Pp369 ISSN 2281-3393

Uchegbu, S. N. (2002). Environmental Management and Protection $2^{\text {nd }}$. Enugu Nigeria Spotlite Publishers

Ukpong, I. E. (1995). Mangrove Soils of the Creek Town, Calabar River Swamp, South Easterm Nigeria, Journal of International Society for Tropical Ecology 36 (1): 103-115. 